\title{
13. SULFUR-ISOTOPE STUDIES OF UPPER ALBIAN SEDIMENTS AT THE CÔTE D'IVOIRE-GHANA TRANSFORM MARGIN'
}

\author{
Ken-ichiro Hisada, ${ }^{2}$ Yoshimichi Kajiwara, ${ }^{2}$ and Takako Yamaguchi ${ }^{2}$
}

\begin{abstract}
The Côte d'Ivoire-Ghana Marginal Ridge in the Atlantic Ocean was drilled during Ocean Drilling Program Leg 159. Sulfur isotopes of Cretaceous sediments were examined, using 28 samples of mudstone and very fine-grained sandstone from Unit $\mathrm{V}$ (late Albian) at Site 959, Unit V (pre-Turonian) at Site 960, Unit III (Bajocian to Maastrichtian) at Site 961, and Unit III (late Albian) at Site 962. Among these, Site 962 is the most westwardly located. Each unit is the basal part of a cored interval. All units except for Unit III at Site 962 are barren of nannofossils or rarely yield poorly preserved nannofossils. The aim of this study was to discriminate the paleogeographical environment by means of sulfur isotopes. The ranges of ${ }^{34} \mathrm{~S}_{\text {sulfide }}$ are as follows: 13.8 to 2.0 at Site $959,13.1$ to -3.9 at Site $960,5.9$ to -27.5 at Site 961, and 12.2 to -15.4 at Site 962. The data might indicate a partially closed anoxic environment for the sulfide deposition with coeval seawater sulfate as a major source of sulfur, as suggested by a gypsum isotope signature (about +15$)$. If the sedimentary features and occurrences of microfossils are taken into consideration, the paleoenvironment of the mid-Cretaceous Côte d'Ivoire-Ghana Marginal Ridge appears to have been a temporarily closed environment in an open sea related to the gateway connecting the proto-North to the South Atlantic Oceans.
\end{abstract}

\section{INTRODUCTION}

Drilling the Côte d'Ivoire-Ghana Transform Margin in the eastern equatorial Atlantic Ocean had both tectonic and paleoceanographic objectives (Mascle, Lohmann, Clift, et al., 1996). The main tectonic objective was to better understand the evolution of transform continental margins. In addition, the main paleoceanographic objective was to document changes in deep and intermediate waters passing through the eastern equatorial Atlantic since the continental breakup in Early Cretaceous times.

A series of four sites was drilled during Leg 159 (Sites 959-962) within the continental crust adjacent to the continent-ocean transition along the transform passive margin of the Côte d'Ivoire-Ghana (Fig. 1). The interplay of tectonic deformation and sedimentation on the Côte d'Ivoire-Ghana Transform Margin is best represented in the spatial and stratigraphic variation of the sediments cored at Sites 959 and 960. Although important information is provided by cores from Sites 961 and 962, the direct contribution for interpreting the paleoenvironmental settings is comparatively limited. On the basis of sections reconstructed from Sites 959 and 960, three principal stages that mark changes in the paleoenvironmental setting have been identified: (1) the Intra-continental to Syntransform Basin Stage, (2) the Marginal Ridge Emergence Stage, and (3) the Passive Margin Stage (Mascle, Lohmann, Clift, et al., 1996).

We obtained a characteristic lithology from Unit V at Site 960, parallel laminated silty claystone. This lithology exhibits alternations of laterally continuous, 0.5 - to 2-mm thick, darker and lighter laminae (Fig. 2). The darker layers are much richer in plant debris and carbonaceous material, whereas the lighter laminae are dominantly rich in quartz and clay minerals. These characteristics led us to conclude that the depositional environment for Subunit VB was a freshwater lake (Mascle, Lohmann, Clift, et al., 1996; p. 174). However, this interpretation was merely based on the observation of the sedimentary

${ }^{1}$ Mascle, J., Lohmann, G.P., and Moullade, M. (Eds.), 1998. Proc. ODP, Sci. Results, 159: College Station, TX (Ocean Drilling Program).

${ }^{2}$ Institute of Geoscience, University of Tsukuba, Ibaraki, Japan 305. hisadak@arsia.geo.tsukuba.ac.jp structure of cores. Thus, we need more evidence to determine the environmental conditions for Subunit VB.

Recently, a criterion for the oxidation-reduction conditions of oceanic sedimentary environments was suggested by Kajiwara and Kaiho (1992). It is based on information on the remarkable sulfurisotopic bimodalism in sedimentary and/or diagenetic sulfides recognized in the global stratigraphic record (Kajiwara, 1989). Kajiwara (1989) compiled available sulfur isotope data for geochronologically well-defined marine shales (NSS: normal shale sulfide) and stratabound massive ore deposits (MOS: major ore sulfide) in the Phanerozoic time. He indicated that their apparent extents of isotopic fractionations show a remarkable bimodal distribution, namely, the average value of NSS (about $-45 \%$ ) is roughly twice as much as that of MOS (about $-20 \%$ ), although their isotopic spectra widely extend and overlap each other. This bimodalism can best be accounted for by a drastic change of environmental oxidation-reduction conditions associated with the discrimination of a microbial habitat. In an aerobefree anoxic basin, the sulfate reduction exclusively occurs without interference from oxidants. Thus, the extent of ${ }^{34} \mathrm{~S} /{ }^{32} \mathrm{~S}$ fractionation of sedimentary and/or diagenetic sulfides, with respect to a contemporaneous source of seawater sulfate, should be restricted within the currently confirmed range of kinetic isotope effects during dissimilar sulfate reduction by anaerobic sulfur-reducing bacteria (e.g., Desulfovibrio spp.), that is, in the range from $-35 \%$ o to $-15 \%$ (Chambers et al., 1975). In an ordinary oxic basin where aerobes are relatively predominant, however, the extent of fractionation is expected more or less to exceed this range, and to give values typically near $-50 \%$ o $\pm 10 \%$, as generally observed in modern oceanic sediments. This is based on the hypothesis that the initial sulfide once produced is reoxidized without a notable isotopic shift by aerobic sulfur-oxidizing bacteria (e.g., Thiobacillus spp.) or by other oxidants, such as dissolved free oxygen, and is then incorporated in a subsequent oxidation-reduction cycle during sedimentary and burial diagenetic processes. The above criterion is applicable to an ordinary "open" oceanic system with an infinite sulfate reservoir. In a "closed," locally anoxic, system with a finite sulfate reservoir, the rate of sulfate reduction largely exceeds the rate of sulfate supply. The Rayleigh distillation process then operates, and the bulk of the sulfides accumulated in the system should be significantly enriched in heavy isotope ${ }^{34} \mathrm{~S}$. 


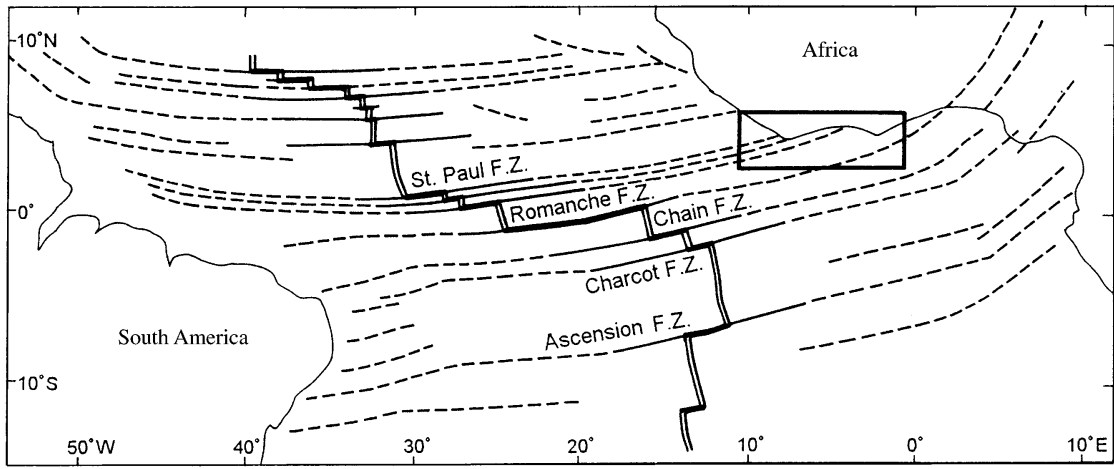

B

Figure 1. A. Geodynamic framework of the Côte d'Ivoire-Ghana Transform Margin. B. Detail of the locations of Sites 959-962. Boxed region in A is shown in more detail in B. F.Z. = fracture zone.

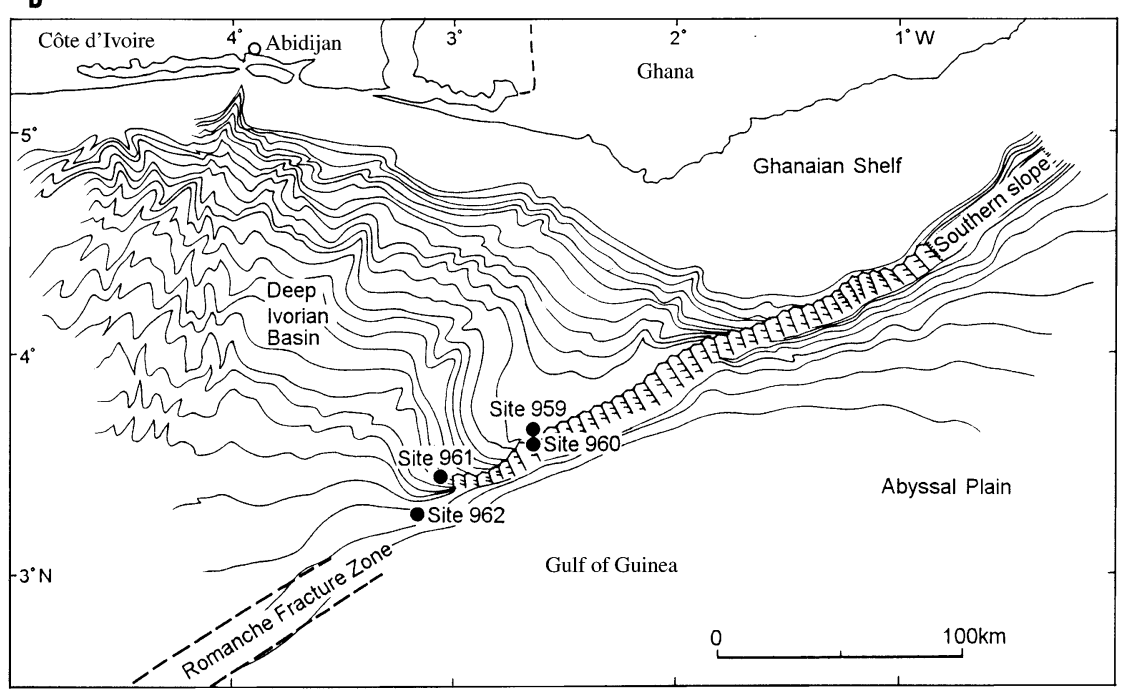

possible that we set a relative valuation on the oxidation-reduction conditions.

\section{LITHOLOGY OF SAMPLED INTERVALS}

We prepared 28 samples for the sulfur-isotopic study. Among these, the samples collected from Sites 959, 961, and 962 were also included to compare the oxidation-reduction conditions among samples and to examine the paleoenvironmental settings. The following is a description of the lithologic units examined in this study.

\section{Site 959}

Three samples used for the sulfur-isotope study were taken from Unit V at Site 959. Unit V comprises mainly quartz sandstone and silty claystone, $77.2 \mathrm{~m}$ thick, which corresponds to interval 159959D-71R-1, $0 \mathrm{~cm}$, through 78R-CC, $20 \mathrm{~cm}$ (total depth [TD]).

Most of the samples are barren of calcareous nannofossils and planktonic foraminifers. However, one sample (Sample 159-959D71R-1, 0-1 cm [1081.7 mbsf]) contains rare, poorly preserved nannofossils. Based on the association of nannofossil taxa, this sample can be placed in the late, but not latest, Albian.

\section{Site 960}

Eight samples used for the sulfur-isotope study were sampled from Unit V at Site 960. Unit V is divided into Subunits VA and VB. Subunit VA comprises sandstone and claystone, and Subunit VB consists of silty sandstone, siltstone, and silty claystone. Four samples were obtained from Subunit VA; the others were from Subunit 
VB. Unit V corresponds to the interval 159-960A-37R-1, $45 \mathrm{~cm}$, through 61R-CC, $4 \mathrm{~cm}$ (TD). The thickness of Subunit VA is $84.1 \mathrm{~m}$, and that of Subunit VB is $38.1 \mathrm{~m}$.

Unit V contains no calcareous or siliceous microfossils. However, the age of Unit IV is placed in the Santonian/Coniacian to Turonian on the basis of calcareous nannofossils and, therefore, Unit V may be assigned a pre-Turonian age.

\section{Site 961}

Ten samples used for the sulfur-isotope study were taken from Unit III at Site 961. Unit III comprises sandstone, silty sandstone, sandy siltstone, clayey siltstone, and silty claystone. The interval of Unit III corresponds to intervals 159-961A-21R-2, $34 \mathrm{~cm}$, to $159-$ 961A-35R-CC, $45 \mathrm{~cm}$ (TD) and 159-961B-1R-1, $0 \mathrm{~cm}$, to 159-961B$19 \mathrm{R}-\mathrm{CC}, 26 \mathrm{~cm}$ (TD). The intervals are 120.2 and $158.3 \mathrm{~m}$ thick, respectively.

Unit III is barren of calcareous and siliceous microfossils. However, two samples (159-961B-9R-CC [313.2 mbsf] and 11R-CC [322.4 mbsf]) contain very rare and very poorly preserved specimens of the dissolution-resistant species Watznaueria barnesae, which has a long stratigraphic range from Bajocian to Maastrichtian.

\section{Site 962}

Seven samples used for the sulfur-isotope analysis were taken from Unit III at Site 962. Unit III consists of claystone with quartz silt, micrite, and nannofossils; clayey siltstone with micrite and nannofossils; calcite-cemented sandstone; calcite-cemented quartz sandy siltstone; limestone; limestone with quartz sand; and limestone with quartz silt. The interval corresponds to interval 159-962D-6R-1, 7 $\mathrm{cm}$, to $159-962 \mathrm{D}-37 \mathrm{R}-\mathrm{CC}, 10 \mathrm{~cm}$ (TD). The thickness of Unit III is $270 \mathrm{~m}$.

All cores recovered from Hole 962D contain Cretaceous nannofossils and planktonic foraminifers. The age of Unit III is placed in the late Albian.

Unit V at Site 960 and Unit III at Site 961 can be correlated with Unit V at Site 959 and Unit III at Site 962 (Mascle, Lohmann, Clift, et al., 1996), although the precise correlation is impossible because of the absence of fossils. Thus, these sediments are assignable to the mid-Cretaceous, probably the Albian.

\section{DESCRIPTION OF SAMPLES}

The grain size of the samples analyzed in the present study differs from site to site. The samples from Site 960 are consistently clay sized, whereas the others are comparatively coarser in size: very fine grained at Site 959; clay sized to very fine grained at Hole 961A; silt sized at Hole 961B; and silt sized to very fine grained at Site 962. The color of samples used herein also varies among the four sites. Brown is predominant in the samples from Site 959, whereas medium to dark gray prevails among the other samples. However, olive gray is recognized in some samples from Site 962. The color appears to depend on the relative amounts of contained minerals.

According to X-ray diffraction observation, mica, albite, potassium feldspar, and quartz are common in all samples, whereas kaolinite is characteristically absent in the samples from Site 960. Chlorite is missing in the samples from Sites 959 and 962 . This mineral is consistently present in the light to dark gray samples from Sites 960 and 961. Carbonate minerals characterize samples from four sites. Calcite is observed only in the samples from Site 962, whereas dolomite is detected only in samples from Hole 961A. Calcite is considered to have originated from calcareous nannofossils. Siderite is contained in all samples from Sites 959 and 960, in some samples from Site 961, and in a single sample from Site 962. Thus, the simultaneous occurrence of siderite and calcite is recognized only in a single sample (Sample 159-962D-25R-2, 76-78 cm; Table 1).
Gypsum was detected in four samples: 159-961B-9R-1, 143-145 $\mathrm{cm}$; 159-962D-10R-2, 36-38 cm; 159-962D-12R-4, 88-90 cm; and 159-962D-25R-1, 76-78 cm. Pyrite is more or less recognized in all samples from all four sites. It often occurs microscopically in minute framboids or globules (usually less than a few micrometers in size; Fig. 3), and it is the common and major sulfur carrier in these samples. The shape of the framboidal aggregates is usually globular, but occasionally flattened. The flattened shape seems to be due to compaction during sediment lithification.

\section{ANALYTICAL METHODS}

Whole-rock sulfur was extracted by treating the samples using the Kiba reagent method summarized by Sasaki et al. (1979). Weighed powdered sample is reacted with $\mathrm{Sn}$ (II)-strong phosphoric acid (Kiba reagent) at $280^{\circ} \pm 10^{\circ} \mathrm{C}$ to extract sulfur as $\mathrm{H}_{2} \mathrm{~S}$ under a stream of purified nitrogen gas. The liberated $\mathrm{H}_{2} \mathrm{~S}$ is quantitatively precipitated as $\mathrm{ZnS}$ in a zinc-acetate solution, then converted to $\mathrm{Ag}_{2} \mathrm{~S}$ by adding a silver-nitrate solution. The $\mathrm{Ag}_{2} \mathrm{~S}$ precipitate is quantitatively filtrated, dried in an oven, and weighed. The bulk sulfur content is determined gravimetrically. For selected samples, a similar treatment is applied using Thode solution, a boiling mixture of $\mathrm{HI}, \mathrm{H}_{3} \mathrm{PO}_{2}$, and $\mathrm{HCI}$ (Thode et al., 1961), to confirm the absence of sulfate sulfur. $\mathrm{Ag}_{2} \mathrm{~S}$ is finally converted to $\mathrm{SO}_{2}$ by vacuum distillation techniques using the method of Robinson and Kusakabe (1975). Ratios of masses 66/64 are measured on a Finnigan Mat Delta-E mass spectrometer equipped with a Nier-type electron impact ion source and a $90^{\circ}$ magnetic sector field. The results are expressed using the conventional standard CDT. The overall experimental accuracy during this study was estimated at $\pm 0.2 \%$ or better.

\section{SULFUR ISOTOPES GEOCHEMISTRY OF SEDIMENTS}

The ${ }^{34} \mathrm{~S}_{\text {sulfide }}$ and sulfur contents of the samples are given in Table 1. The analytical data are summarized in Figures 4 through 7, together with the inferred value of coeval seawater sulfate after Claypool et al. (1980). The ranges of ${ }^{34} \mathrm{~S}_{\text {sulfide }}$ are as follows: 13.8 to 2.0 at Site 959, 13.1 to -3.9 at Site 960, 5.9 to -27.5 at Site 961, and 12.2 to -15.4 at Site 962 . The sulfur contents are as follows: 4630 to 5680 ppm at Site 959, 610 to 13,270 ppm at Site 960, 2330 to $14,850 \mathrm{ppm}$ at Site 961 , and 5450 to 20,540 ppm at Site 962.

In the case of Site 959, there was insufficient ${ }^{34} S_{\text {sulfide }}$ data to determine a trend downhole. However, the ${ }^{34} S_{\text {sulfide }}$ values are above 0 . The ${ }^{34} \mathrm{~S}_{\text {sulfide }}$ value at Site 960 is nearly 0 or slightly less than 0 , whereas a single datum indicates about 13.8 , which is the highest value among the samples analyzed in this study. In marked contrast with Sites 959 and 960, there are remarkable shifts ranging over $25 \%$ at Site 961 . The uphole decrease in the ${ }^{34} \mathrm{~S}_{\text {sulfide }}$ values can be detected at Site 962 , although there is a long, unmeasured interval. The ${ }^{34} \mathrm{~S}_{\text {sulfide }}$ values range from $-8.6 \%$ o to $-15.4 \%$, except for two downhole data at Site 962 . It is worth noting that the single datum for gypsum (Sample $159-962 \mathrm{D}-10 \mathrm{R}-2,36-38 \mathrm{~cm}$ ) gives $15.4 \%$, which is similar to the best estimates of contemporaneous seawater value (Claypool et al., 1980).

\section{DISCUSSION \\ Recognition of Anoxic Environment}

The bulk sulfides analyzed for Leg 159 have ${ }^{34} \mathrm{~S}$ values ranging from $-27.5 \%$ o to $13.8 \%$. The single datum obtained for gypsum gives $15.4 \%$, which is fairly consistent with the currently assumed value for a mid-Cretaceous oceanic sulfate (16\%o; Claypool et al., 1980), suggestive of the possible incorporation of seawater sulfate as a major source of sulfur in the studied sedimentary basin. Sawlowicz 
Table 1. Description of samples and sulfur-isotopic data.

\begin{tabular}{|c|c|c|c|c|c|c|c|c|c|c|c|c|c|c|c|}
\hline \multirow{3}{*}{$\begin{array}{l}\text { Hole: } \\
\text { Core, section: } \\
\text { Interval }(\mathrm{cm}) \text { : }\end{array}$} & \multicolumn{3}{|c|}{ 159-959D- } & \multicolumn{8}{|c|}{$159-960 \mathrm{~A}-$} & \multicolumn{4}{|c|}{ 159-961A- } \\
\hline & $74 \mathrm{R}-1$ & $75 \mathrm{R}-1$ & 78R-1 & $42 \mathrm{R}-1$ & $46 \mathrm{R}-2$ & 50R-1 & $53 \mathrm{R}-1$ & $55 \mathrm{R}-1$ & $56 \mathrm{R}-1$ & $58 \mathrm{R}-1$ & $58 \mathrm{R}-3$ & $21 \mathrm{R}-2$ & $22 \mathrm{R}-1$ & 29R- & $34 \mathrm{R}-\mathrm{C}$ \\
\hline & $128-132$ & $102-105$ & $15-17$ & $147-150$ & $124-126$ & 44-46 & $67-69$ & $7-10$ & 88-91 & $25-27$ & $14-16$ & $120-122$ & $60-62$ & $23-26$ & $14-17$ \\
\hline Size: & Very fine & Very fine (silt) & Very fine & Clay & Clay & Clay & Clay & Clay & Clay & Clay & Clay & Silt & Silt & Clay & Very fine \\
\hline Color: & Pale brown & Pale brown & $\begin{array}{l}\text { Grayish } \\
\text { brown }\end{array}$ & Dark gray & $\begin{array}{l}\text { Light gray } \\
\text { and medium } \\
\text { light gray }\end{array}$ & $\begin{array}{l}\text { Medium dark } \\
\text { gray }\end{array}$ & Grayish black & $\begin{array}{l}\text { Light gray } \\
\text { and medium } \\
\text { gray }\end{array}$ & $\begin{array}{l}\text { Medium light } \\
\text { gray and } \\
\text { medium dark } \\
\text { gray }\end{array}$ & $\begin{array}{l}\text { Medium gray } \\
\text { and dark gray } \\
\end{array}$ & $\begin{array}{l}\text { Medium gray } \\
\text { and dark gray }\end{array}$ & Medium gray & $\begin{array}{l}\text { Medium light } \\
\text { gray and } \\
\text { medium gray }\end{array}$ & $\begin{array}{l}\text { Medium dark } \\
\text { gray }\end{array}$ & $\begin{array}{l}\text { Medium light } \\
\text { gray }\end{array}$ \\
\hline $\begin{array}{l}\text { Pyrite } \\
\text { Gynsum }\end{array}$ & + & + & + & + & + & ++ & + & + & + & + & ++ & ++ & ++ & ++ & ++ \\
\hline Calcite & & & & & & & & & & & & ++ & + & ++ & + \\
\hline Dolomite & & & & & & & & & & & & ++ & + & ++ & \\
\hline Siderite & ++ & ++ & ++ & + & ++ & ++ & ++ & ++ & ++ & ++ & + & & & + & + \\
\hline Chlorite & & & & ++ & ++ & ++ & ++ & ++ & ++ & ++ & ++ & + & + & & ++ \\
\hline Kaolinite & ++ & ++ & ++ & & & & & & + & + & & + & + & + & + \\
\hline Mica & + & + & + & + & ++ & ++ & ++ & ++ & + & ++ & ++ & ++ & + & + & + \\
\hline Albite & + & + & + & + & ++ & + & + & + & + & + & + & ++ & ++ & + & + \\
\hline K-feldspar & + & + & + & + & + & + & + & + & + & + & + & + & + & + & + \\
\hline Quartz & ++ & ++ & ++ & ++ & ++ & ++ & ++ & ++ & ++ & ++ & ++ & ++ & ++ & ++ & ++ \\
\hline $\begin{array}{l}\delta^{34} \mathrm{~S}(\%): \\
\text { Sulfur content (ppm): }\end{array}$ & $\begin{array}{l}3.5 \\
5320\end{array}$ & $\begin{array}{l}13.8 \\
4630\end{array}$ & $\begin{array}{l}2.0 \\
5680\end{array}$ & $2710^{-1.4}$ & $\begin{array}{l}2.4 \\
610\end{array}$ & $\begin{array}{l}13.1 \\
2690\end{array}$ & $\begin{array}{l}1.2 \\
8210\end{array}$ & $\begin{array}{l}0.4 \\
5010\end{array}$ & $12050^{-3.9}$ & $\begin{array}{l}-0.4 \\
7840\end{array}$ & 13270 & $\begin{array}{l}-21.7 \\
11140\end{array}$ & 14850 & $\begin{array}{l}-8.8 \\
3580\end{array}$ & $\begin{array}{l}3.4 \\
8230\end{array}$ \\
\hline
\end{tabular}

Table 1 (continued)

\begin{tabular}{|c|c|c|c|c|c|c|c|c|c|c|c|c|c|}
\hline \multirow{3}{*}{$\begin{array}{l}\text { Hole: } \\
\text { Core, section: } \\
\text { Interval }(\mathrm{cm}) \text { : }\end{array}$} & \multicolumn{6}{|c|}{ 159-961B- } & \multicolumn{7}{|c|}{ 159-962D- } \\
\hline & $7 \mathrm{R}-3$ & 9R-1 & 10R-4 & 11R-1 & $12 \mathrm{R}-1$ & 16R-2 & 9R-4 & 10R-2 & $12 \mathrm{R}-4$ & $25 \mathrm{R}-1$ & $28 \mathrm{R}-2$ & 34R-1 & 37R-3 \\
\hline & $53-55$ & $143-145$ & $20-22$ & $14-17$ & $36-38$ & $132-134$ & $65-66$ & $36-38$ & $88-90$ & $76-78$ & $89-91$ & $145-147$ & $77-80$ \\
\hline $\begin{array}{l}\text { Size: } \\
\text { Color: }\end{array}$ & $\begin{array}{c}\text { Silt } \\
\text { Light gray } \\
\text { and medium } \\
\text { light gray }\end{array}$ & $\begin{array}{c}\text { Silt } \\
\text { Medium gray }\end{array}$ & $\begin{array}{l}\text { Silt } \\
\text { Medium light } \\
\text { gray }\end{array}$ & $\begin{array}{l}\text { Silt } \\
\text { Medium dark } \\
\text { gray }\end{array}$ & $\begin{array}{c}\text { Silt } \\
\text { Dark gray }\end{array}$ & $\begin{array}{c}\text { Silt } \\
\text { Medium gray }\end{array}$ & $\begin{array}{l}\text { Very fine } \\
\text { Olive gray }\end{array}$ & $\begin{array}{c}\text { Silt } \\
\text { Light olive } \\
\text { gray and } \\
\text { olive gray }\end{array}$ & $\begin{array}{c}\text { Silt } \\
\text { Medium dark } \\
\text { gray }\end{array}$ & $\begin{array}{c}\text { Silt } \\
\text { Light olive } \\
\text { gray }\end{array}$ & $\begin{array}{l}\text { Very fine } \\
\text { Light gray } \\
\text { and olive } \\
\text { gray }\end{array}$ & $\begin{array}{l}\text { Very fine } \\
\text { Light gray } \\
\text { and olive } \\
\text { gray }\end{array}$ & $\begin{array}{c}\text { Very fine, silt } \\
\text { Medium light } \\
\text { gray } \\
\text { and olive } \\
\text { gray }\end{array}$ \\
\hline Pyrite & + & + & + & + & + & + & + & + & + & + & + & + & \\
\hline $\begin{array}{l}\text { Gypsum } \\
\text { Calcite }\end{array}$ & ++ & ++ & $\begin{array}{l}++ \\
++\end{array}$ & + & ++ & & & & & & & & \\
\hline Dolomite & ++ & ++ & & & & & & & & & & & \\
\hline Siderite & & & & & & + & & & & + & & & \\
\hline $\begin{array}{l}\text { Chlorite } \\
\text { Kaolinite }\end{array}$ & $\begin{array}{l}+ \\
+\end{array}$ & + & + & + & + & & & & & & & & \\
\hline Kaolinite & + & + & + & & + & + & + & & + & & & & \\
\hline Mica & ++ & ++ & ++ & ++ & ++ & ++ & + & + & + & + & + & + & + \\
\hline Albite & + & + & + & ++ & ++ & + & + & + & + & + & + & + & + \\
\hline K-feldspar & + & + & + & + & + & + & + & + & + & + & + & + & + \\
\hline Quartz & ++ & + & ++ & ++ & ++ & + & ++ & ++ & ++ & ++ & + & + & + \\
\hline $\begin{array}{l}\delta^{34} \mathrm{~S}(\%): \\
\text { Sulfur content(ppm): }\end{array}$ & $2330^{2.9}$ & $\begin{array}{l}-27.5 \\
7190\end{array}$ & $\begin{array}{r}5.2 \\
2900\end{array}$ & $\begin{aligned}-3.3 \\
2820\end{aligned}$ & $\begin{array}{l}-16.2 \\
5870\end{array}$ & $\begin{array}{r}5.9 \\
3600\end{array}$ & 6010 & $\begin{array}{l}-14.0 \\
8260\end{array}$ & $\begin{array}{l}-15.4 \\
5450\end{array}$ & $\begin{array}{c}-13.8 \\
10180\end{array}$ & $\begin{array}{c}-10.6 \\
10260\end{array}$ & $\begin{array}{r}12.2 \\
7310\end{array}$ & $\begin{array}{c}8.2 \\
20540\end{array}$ \\
\hline
\end{tabular}




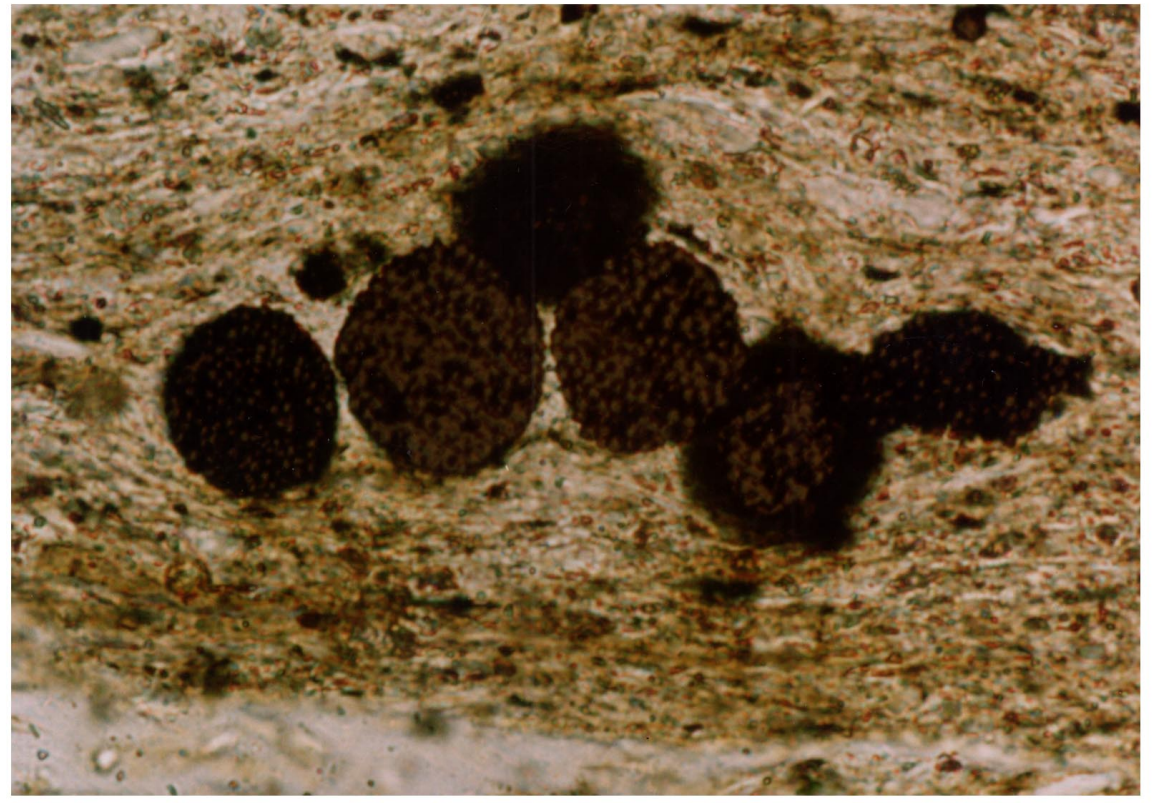

A

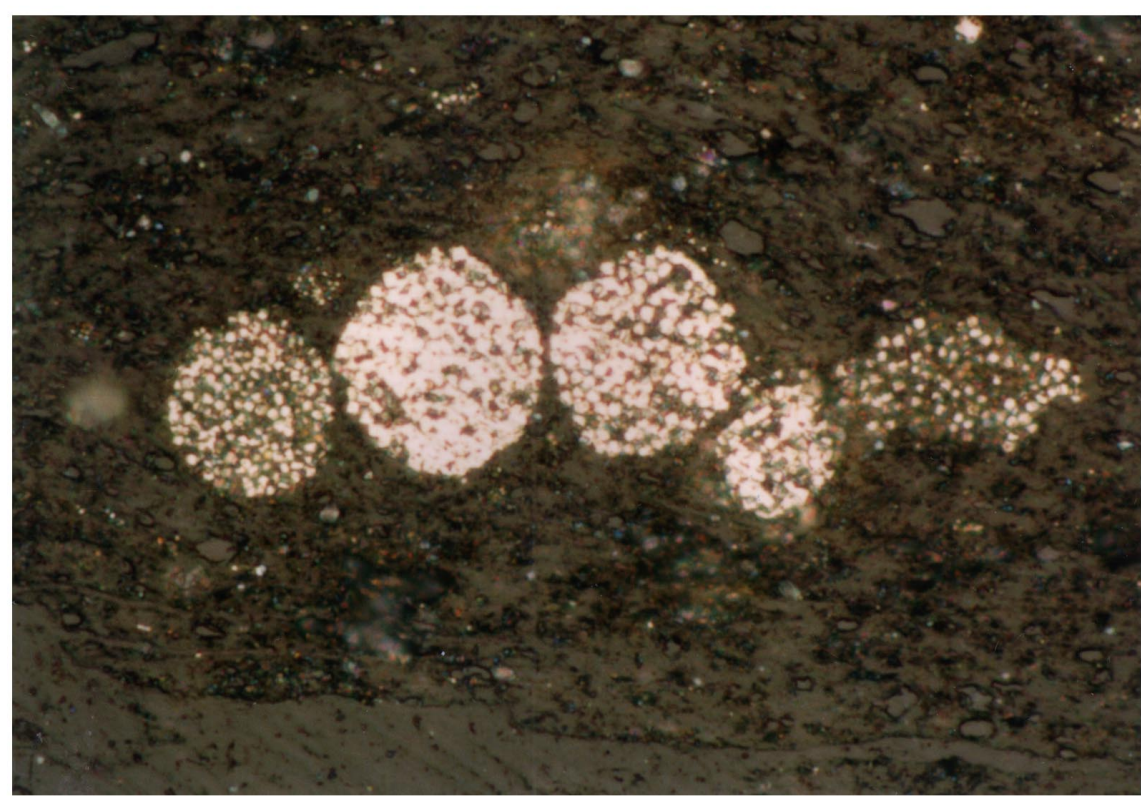

B

(1993) summarized different genetic origins that have been proposed for framboidal pyrite, ranging from a purely inorganic origin through indirect biogenic formation to a direct biogenic origin. In sedimentary rocks, framboidal pyrites are generally considered syngenetic (e.g., Degens et al., 1972) or early diagenetic components (e.g., Love and Amstuzt, 1966). As evidenced by the common occurrence of framboidal pyrite (Fig. 3), it appears that the sulfides were essentially formed by the microbial reduction of contemporaneous seawater sulfate.

The apparent extent of fractionation in the total sulfides, with respect to the contemporaneous seawater sulfate $(+16 \%)$, is in the range from $-35 \%$ o to $0 \%$ (Figs. 4-7), with one insignificant exception (about-42\%o) from Site 961 (Fig. 6). As far as we accept the criterion reviewed above, the present sulfur-isotope data could thus provide strong evidence for the possible development of a partially and intermittently closed, anoxic environment in the late Albian sedimentary basin. It appears that the closed, anoxic sedimentary basin exist-
Figure 3. Framboidal pyrite in sediments in Sample 159-960A-56R-1, 88-91 cm. Scale bar $=10 \mu \mathrm{m}$. A. Reflected light. B. Transmitted light.

ed at Sites 959 and 960, and that rare influxes of open seawater into the basin might occur, as suggested by a rare occurrence of nannofossils. On the other hand, there are remarkable changes ranging from closed to open anoxic conditions at Site 961, and probably at Site 962. Especially at Site 961, nannofossils are obtained from claystone and clayey siltstone above and below siltstone, whose ${ }^{34} \mathrm{~S}_{\text {sulfide }}$ suggest closed, anoxic conditions (Fig.6). The ${ }^{34} \mathrm{~S}_{\text {sulfide }}$ value from the lowermost part of cored sample at Site 962 suggests the closed, anoxic conditions, though all cored samples yield nannofossils. Thus, even though the sedimentary basin was an open, anoxic system, it might be strongly influenced by an influx of oxygen-depleted nutrient-rich water, as suggested by Jenkyns (1980).

\section{Paleoenvironment of Transform Margin}

The succession of Unit V, especially Subunit VB, at Site 960 is most typical of inferred anoxic environmental sediments, in terms of 


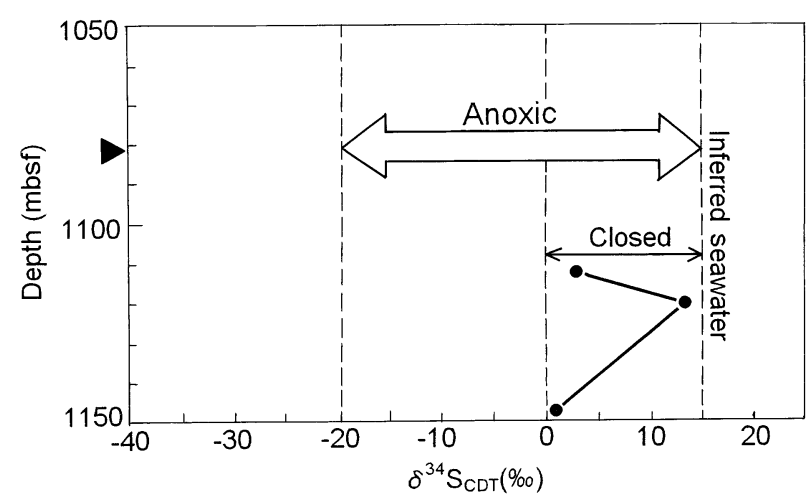

Figure 4. Sulfur-isotope data from Site 959 . The assumed mean ${ }^{34} \mathrm{~S} /{ }^{32} \mathrm{~S}$ value (inferred seawater) for the mid-Cretaceous (Claypool et al., 1980) is given. Solid triangle $=$ the occurrence of nannofossils.

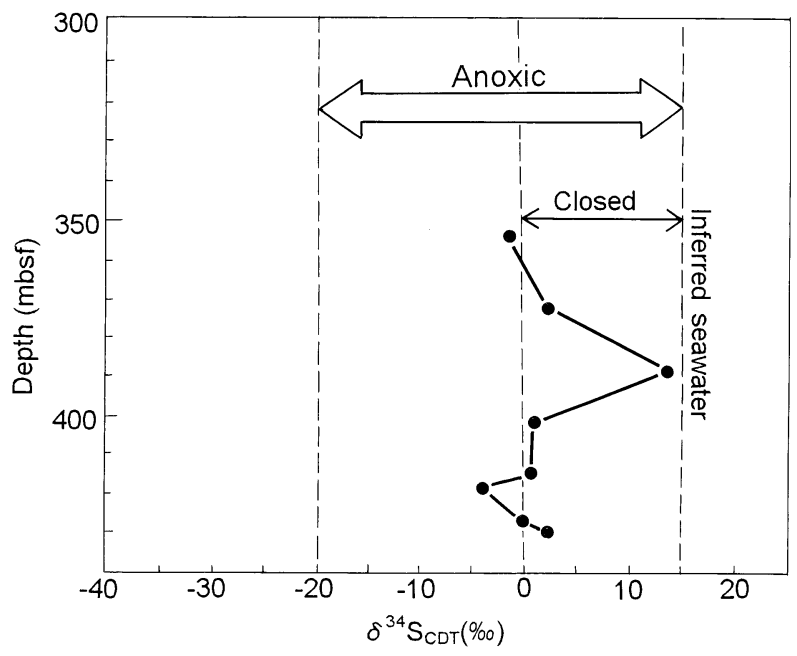

Figure 5. Sulfur-isotope data from Site 960 . The assumed mean ${ }^{34} \mathrm{~S} /{ }^{32} \mathrm{~S}$ value (inferred seawater) for the mid-Cretaceous (Claypool et al., 1980) is given.

sedimentary structures and lithologic features (Mascle, Lohmann, Clift, et al., 1996). The lower part of Subunit VB (interval 159-960A$54 \mathrm{R}-1,0 \mathrm{~cm}$, through 61R-CC [TD]) consists of millimeter-scale parallel laminated silty claystone. These prominent characteristics are consistent with varves or rhythmites formed in a freshwater lake environment (Reineck and Singh, 1980) and are similar to features observed at Deep Sea Drilling Project Site 380 in the Black Sea (Shipboard Scientific Party, 1978). The silty claystone of Subunit VB is overlain by massive to finely laminated siliciclastic sediments of Subunit VA, in which claystones are slightly to heavily bioturbated and contain a few fossils. If the interpretation of Subunit VB as a deep lacustrine environment is correct, then Subunit VA could reflect the onset of brackish conditions as a result of inundation by marine waters. Thus, the succession of Unit V at Site 960 indicates the depositional environmental change from freshwater to brackish water. As mentioned before, the oxidation-reduction conditions determined from the sulfur-isotope values from Site 960 suggest a closed, anoxic system. This seems to be consistent with the scenario established by sedimentary structures and lithologic features, and is probably also applicable to the case of Site 959.

Guiraud and Maurin (1992) concluded that two stages of the Early Cretaceous rift development occurred with respect to the reconstruction of the opening of the southern Atlantic: the Neocomian to early

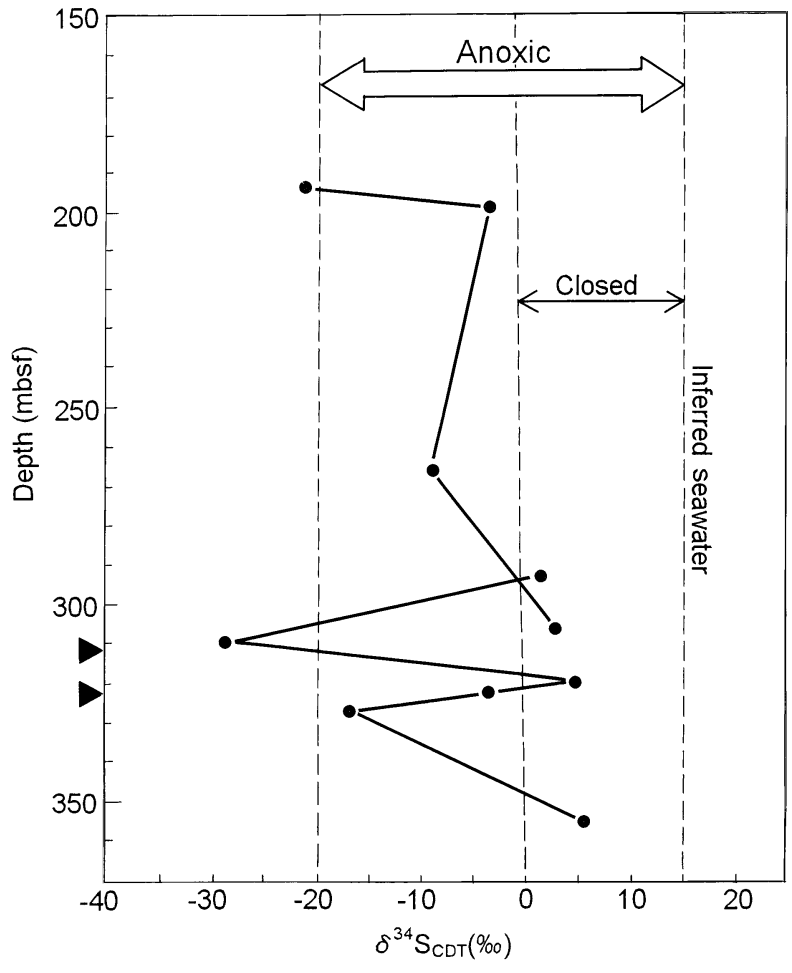

Figure 6. Sulfur-isotope data from Site 961 . The assumed mean ${ }^{34} \mathrm{~S} /{ }^{32} \mathrm{~S}$ value (inferred seawater) for the mid-Cretaceous (Claypool et al., 1980) is given. Solid triangle $=$ the occurrence of nannofossils.

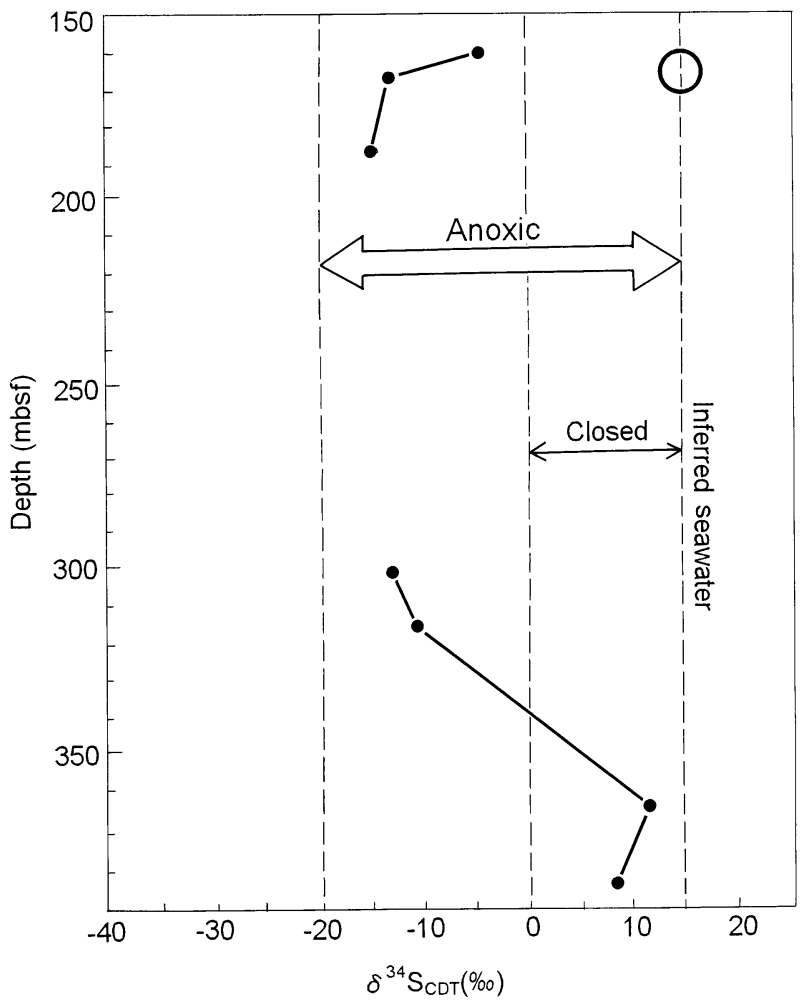

Figure 7. Sulfur-isotope data from Site 962 . The assumed mean ${ }^{34} \mathrm{~S} /{ }^{32} \mathrm{~S}$ value (inferred seawater) for the mid-Cretaceous (Claypool et al., 1980) is given. Open circle $={ }^{34} \mathrm{~S} /{ }^{32} \mathrm{~S}$ value for sulfate (gypsum). 
Aptian and the middle-late Aptian to Albian. During the latter stage, dextral transform movement along the equatorial Atlantic fracture system (Gulf of Guinea) accelerated, causing deformation of the African margin (Mascle et al., 1988). This deformation may have produced the geomorphological complexity in the proto-equatorial Atlantic, namely, the coastal basins of the Ivory Coast during the Albian were inferred to have been identified as part of the transition from rift to passive margin (Guiraud and Maurin, 1992). The very thick continental clastics were deformed by dextral transtensional and transpressional motions along major shear faults, as indicated by the presence of pull-apart basins and folded highs (Mascle et al., 1988; Basile et al., 1992). According to the paleogeographic and tectonic reconstruction of the Côte d'Ivoire-Ghana Marginal Ridge (Mascle, Lohmann, Clift, et al., 1996), Sites 959 and 960 appeared to be located within a transform basin bounded by topographic highs, where the strait connected the basin and the westward open sea. This suggests that Sites 959 and 960 were much more influenced by closed, anoxic conditions, whereas more oxic conditions prevailed at Sites 961 and 962.

\section{CONCLUSIONS}

The sulfur-isotope study reveals that almost all the sediments of probably upper Albian age cored at Sites 959-962 were deposited in anoxic environments. This conclusion is in accordance with the results obtained from the Lithologic features and sedimentary structures. The mid-Cretaceous sedimentary basins located in the Côte d'Ivoire-Ghana Maginal Ridge seem to be a temporarily closed environment in an open sea related to the gateway connecting the protoNorth to the South Atlantic Oceans. It is also worth noting that the only datum for gypsum at Site 962 gives $15.4 \%$ o, which is similar to the currently assumed contemporaneous seawater value. This implies that Site 962 was already highly influenced by seawater in the late Albian.

\section{ACKNOWLEDGMENTS}

Ken-ichiro Hisada is indebted to ODP, the Leg 159 Shipboard Scientific Party, and the Sedco and Schlumberger shipboard crews, who provided the geologic background and samples for this research, and we especially thank the other Leg 159 sedimentologists, Maryanne Holmes, Kyger C. Lohmann, Francisca E. Oboh, Thomas Pletch, and Kari O. Strand. We also wish to thank Christophe Basile for finding important references.

\section{REFERENCES}

Basile, C., Brun, J.P., and Mascle, J., 1992. Structure et formation de la marge transformante de Côte d'Ivoire-Ghana: apports de la sismique réflexion et de la modélisation analogique. Bull. Soc. Geol. Fr., 163:207216.

Chambers, L.A., Trudinger, P.A., Smith, J.W., and Burns, M.S., 1975. Fractionation of sulfur isotopes by continuous cultures of Desulfovibrio desulfuricans. Can. J. Microbiol., 21:1602-1609.

Claypool, G.E., Holser, W.T., Kaplan, I.R., Sakai, H., and Zak, I., 1980. The age curves of sulfur and oxygen isotopes in marine sulfate and their mutual interpretation. Chem. Geol., 28:199-260.

Degens, E.T., Okada, H., Honjo, S., and Hathaway, J.C., 1972. Microcrystalline sphalerite in resin globules suspended in Lake Kivu, East Africa. Miner. Deposita, 7:1-12.

Guiraud, R., and Maurin, J.C., 1992. Early Cretaceous rifts of western and Central Africa: an overview. Tectonophysics, 213:153-168.

Jenkyns, H.C., 1980. Cretaceous anoxic events: from continents to oceans. $J$. Geol. Soc. London, 137:171-188.

Kajiwara, Y., 1989. Potential contribution of biologically controlled sulfur sources to ore genesis. Ann. Rep. Inst. Geosci. Univ. Tsukuba, 15:96101.

Kajiwara, Y., and Kaiho, K., 1992. Oceanic anoxia at the Cretaceous/Tertiary boundary supported by the sulfur isotopic record. Palaeogeogr., Palaeoclimatol., Palaeoecol., 99:151-162.

Love, L.G., and Amstutz, G.G., 1966. Review of microscopic pyrite. Fortschr. Miner., 43:273-309.

Mascle, J., Blarez, E., and Marinho, M., 1988. The shallow structures of the Guinea and Ivory Coast-Ghana transform margins: their bearing on the Equatorial Atlantic Mesozoic evolution. Tectonophysics, 188:193-209.

Mascle, J., Lohmann, G.P., Clift, P.D., et al., 1996. Proc. ODP, Init. Repts., 159: College Station, TX (Ocean Drilling Program).

Reineck, H.E., and Singh, I.B., 1980. Depositional Sedimentary Environments (2nd ed.): Berlin (Springer-Verlag).

Robinson, B.R., and Kusakabe, M., 1975. Quantitative preparation of $\mathrm{SO}_{2}$ for ${ }^{34} \mathrm{~S} /{ }^{32} \mathrm{~S}$ analyses from sulfides by combustion with cuprous oxide. Anal. Chem., 47:1179-1181.

Sasaki, A., Arikawa, Y., and Folinsbee, R.E., 1979. Kiba reagent method of sulfur extraction applied to isotope work. Bull. Geol. Surv. Jpn., 30:241245.

Sawlowicz, Z., 1993. Pyrite framboids and their development: a new conceptual mechanism. Geol. Rundsch., 82:148-156.

Shipboard Scientific Party, 1978. Site 380. In Ross, D.A., Neprochnov, Y.P., et al., Init. Repts. DSDP, 42 (Pt. 2): Washington (U.S. Govt. Printing Office), 119-291.

Thode, H.G., Monster, J., and Dunford, H.B., 1961. Sulphur isotope geochemistry. Geochim. Cosmochim. Acta, 25:158-174.

Date of initial receipt: 16 September 1996

Date of acceptance: 1 May 1997

Ms 159SR-011 